\title{
CYBER SEX MENURUT PERSPEKTIF HUKUM ISLAM DAN UNDANG-UNDANG NO. 44 TAHUN 2008 TENTANG PORNOGRAFI
}

\author{
Oleh: \\ Fawwas ${ }^{1} \&$ Achmad $^{2}$ \\ Email: rosulahmad9@gmail.com
}

\begin{abstract}
Pornography is an old problem that cannot be addressed by the provisions contained in the Criminal Code (Wetbook van Starvrecht Nederlandsch-Indie). The negative impact of pornography is increasingly worrisome, including: the occurrence of rape, adultery and abortion. Then the Indonesian Ulema Council (MUI) issued a fatwa Number 287 of 2001 concerning the prohibition against pornography and porno-action, because it was guided by the law on the many disadvantages of the benefits arising from pornography and porno-action and the prohibition against acts of approaching adultery. Because pornography and porno-action can be closer to adultery. In Islam also recognizes freedom of expression and opinion, does not mean freedom is used for negative purposes such as pornography and porno-action. But freedom of expression and opinion must be accountable not only to humans but also to Allah SWT. Islam teaches that the main purpose of life and human life is to get the pleasure of Allah alone. And accountable for all his actions while living in the world, including treating and utilizing his body as a mandate of Allah SWT.
\end{abstract}

Key words: cyber sex, Islamic Criminal Law, Law Number 44 of 2008

\section{Pendahuluan}

Perkembangan teknologi dan informasi pada abad ke-21 berkembang pesat seperti komputer yang pada awalnya merupakan mesin penghitung yang cepat dapat menerima informasi input digital. ${ }^{3}$ Teknologi informasi menghasilkan internet yang begitu cepat mengubah wajah dunia seperti sekarang ini. Internet membuka cakrawala informasi, pengetahuan dan apapun fakta-fakta dari seluruh penjuru dunia karena itu teknologinya

\footnotetext{
1 Alumni S-1 Prodi Hukum Pidana Islam STAI Syaichona Moh. Cholil Bangkalan

2 Dosen Prodi Hukum Pidana Islam STAI Syaichona Moh. Cholil Bangkalan

3 Jogiyanto Hartono, Pengenalan Computer, Yogyakarta : Andi Offset, 1999, hlm.2.
} 
disebut virtual technology atau teknologi maya, salah satunya mengakses internet berarti komunikasi dengan tampilan teks yang monoton, ${ }^{4}$ dan hal tersebut menjadikan informasi yang terbuka dalam arti tidak terlihat batasan-batasan suatu negara.

Teknologi informasi dapat menunjang laju pertumbuhan berbagai aspek kehidupan. Internet merupakan sebuah ruangan informasi dan komunikasi yang dapat mempercepat penyebaran informasi ilmu pengetahuan serta menambah wawasan serta kemudahan-kemudahan membantu manusia dalam pekerjaannya. Saat ini, internet telah membentuk masyarakat dengan kebudayaan baru. Masyarakat yang tidak lagi dihalangi oleh batas-batas teritorial antara negara yang terdahulu ditetapkan sangat rigid sekali. Masyarakat baru dengan kebebasan beraktivitas dan berkreasi yang paling sempurna.

Namun, dibalik gemerlap itu, internet juga melahirkan keresahankeresahan baru. Di antaranya, muncul kejahatan yang lebih canggih dalam bentuk "cyber crime". Hal ini ditandai dengan berkembang pesatnya situs porno dalam berbagai tampilan situs yang sangat menggoda, atu tempat penyebaran kabar bohong (hoax) yang paling efektif. Bahkan berbagai data terakhir menunjukkan transaksi terbesar perdagangan melalui internet diperoleh dari bisnis pornografi ini. ${ }^{5}$

Cyber crime menggunakan media komunikasi dan komputer, untuk kejahatan ini tentu saja dilakukan oleh orang yang mahir dalam menggunakan komputer dengan mencari kelemahan dan kelebihan sesuatu dari hardware dan softwarenya. Kejahatan tersebut dapat menimbulkan pengaruh dalam beberapa aspek seperti: militer, pemerintahan, politik, ekonomi, dan sosial, dan salah satu bentuk kejahatan tersebut adalah cyber sex.

Cyber sex dapat diakses tanpa mengenal batasan umur dalam artian jika dia mahir atau setidaknya tahu maka dia dapat mengakses hal tersebut. Cyber sex cenderung dapat memberikan pengaruh negatif pada remaja, karena rasa ingin tahu, pergaulan yang kurang baik dan daya pikir yang

\footnotetext{
${ }^{4}$ Syarif Hidayatullah dkk, Islam Virtual Jakarta, Bogor : kencana, 2004, hal. 9.

${ }^{5}$ Edmon Makarim, Kompilasi Hukum Telematika, Jakarta : PT. Raja Grafindo
} Persada, 2003, cet. Ke-1, Hal. 8. 
terkadang tidak melihat prospek apa yang akan dihadapi. Namun pada dasarnya dengan daya pikir manusia yang berkembang dan pendidikan yang memadai serta adanya financial yang cukup, para remaja mampu menjalajahi situs seks tersebut tanpa batas dan tanpa pengawasan.

Menurut hasil penelitian Nasional Center for Technology eEucation anak di bawah umur mengenal pornografi dari internet, sekitar $24 \%$ anak berusia 8-17 tahun berada di Asia dan 86\% anak dibawah umur yang masuk ke chatroom (ruang), sering melakukan percakapan yang dilarang dengan teman cybernya. ${ }^{6}$

\section{Pengertian Cyber Sex}

Cyber sex didefinisikan sebagai penggunaan internet untuk terlibat dalam aktivitas kesenangan seksual, seperti: melihat gambar-gambar erotis, berpartisipasi dalam chatting tentang seks, saling tukar menukar gambar atau email tentang seks, dan lain sebagainya, yang terkadang diikuti oleh masturbasi. Hal serupa diungkapkan oleh Carners, Delmonico dan Griffin bahwa cyber sex adalah mengakses pornografi di internet, terlibat dalam real-time yaitu percakapan tentang seksual online dengan orang lain, dan mengakses multimedia software. Maheu) juga mendefenisikan cyber sex dimana terjadi ketika orang menggunakan komputer yang berisi tentang teks, suara dan gambar yang didapatkan dari software atau internet untuk stimulus seksual dan secara khusus mencakup dua atau lebih orang berinteraksi diinternet yang membangkitkan gairah seksual satu dengan yang lainnya. ${ }^{7}$

Cyber sex bukan lagi sebuah seni bercinta, akan tetapi dengan melihat, mendengar, dan merasakan tanpa harus berhubungan badan atau terjadi kontak fisik. Pada intinya hanya menggunakan imajinasi dalam meraih kepuasan seksual. Banyak kalangan menganggap bahwa cyber sex adalah kebohongan, meskipun tidak melibatkan kontak secara fisik. Meskipun tidak terjadi kontak fisik selama melakukan cyber sex, namun pelaku cyber

\footnotetext{
6 “Artikel Hukum" http://www.glorianet.org/internet/artikel.html, diakses pada tanggal 11 januari 2018 pukul 10. 27

${ }^{7}$ Didik M. Arif Mansur dkk, Ciber Law Aspek Hukum Teknologi, Bandung : PT Rafika Aditama, 2006, cet. Ke-1, hlm. 25.
} 
sex ini dapat mengeluarkan semua fantasi seksual pada orang lain, selain pasangan tetapnya. Banyak yang menganggap bahwa pelaku tidak cukup puas dengan yang telah didapat dari pasangan tetapnya. Ada juga sebagian berpendapat bahwa terkadang seseorang itu merasa cukup puas dengan hubungannya selama ini. Ia pun cenderung berfantasi secara seksual untuk kebutuhan seksualnya. Cyber sex ini juga bisa menjadi hobi yang menyehatkan selama kita melakukannya dengan level yang wajar atau sebagai variasi seks yang dilakukan dengan pasangan tetap. Mungkin banyak dari kita semua membutuhkan suatu tantangan dan virtual sex semacam ini. ${ }^{8}$

Cyber sex merupakan media atau alat komunikasi yang dibuat menyampaikan gagasan-gagasan tentang seks atau pornografi atau porno aksi melalui sarana komputer dengan jaringan internet. Cyber sex itu sendiri erat kaitannya dengan pornografi. Cyber sex merupakan salah satu kejahatan cyber crime yang dilakukan secara diam-diam atau sembunyi-sembunyi. Situs ini dapat diakses dengan bebas, meskipun orang yang mengakses ini belum cukup umur.

\section{Penyebab Timbulnya Cyber Sex}

Pengguna internet untuk mengakses situs-situs porno terkadang sangat sulit dihindari, mengingat situs-situs ini sangat banyak dalam dunia maya. Dengan menjamurnya situs sex di internet. Ini timbul karena ada hal-hal yang didasari dengan rasa ketidakpuasan dan rasa keingintahuan, seperti:

1. Sosial ${ }^{9}$

Manusia dikatakan makhluk sosial yang artinya tidak bisa hidup sendiri-sendiri selalu membutuhkan orang lain. Manusia berinteraksi secara individu maupun kelompok. Dengan interaksi itu seseorang dapat mengetahui informasi-informasi baik secara bersentuhan langsung (secara fisik) maupun tidak. ${ }^{10}$ Laporan lembaga yang merupakan bagian National Pepulation and Family Development Boord mengatakan bahwa sitrus-situs

\footnotetext{
${ }^{8}$ Ibid.

${ }^{9}$ Taufik Rahman Dhohiri dkk, Sosiologi, Jakarta : Yudistira, 2000, hal. 27.

${ }^{10}$ Taufik Rahman Dhohiri dkk, Sosiologi, Jakarta : Yudistira, 2000, hal. 27.
} 
porno menyebabkan para remaja mendapatkan pengertian yang salah tentang seks karena tidak adanya tutunan orang tua dalam hal itu. Ini menjadi alasan meningkatnya kejahatan seksual terhadap wanita dan anakanak. Seperti diketahui situs-situs porno dan layanan seks lainnya begitu mudah didapatkan lewat internet, baik yang gratis maupun yang harus membayar untuk bisa mengaksesnya. Bahkan situs-situs yang menawarkan pornografi merupakan bagian bisnis dunia maya yang bertahan di kala situs-situs yang lain berjatuhan. ${ }^{11}$

Dari interaksi tersebut muncul rasa keingintahuan tentang informasi yang didapat, seperti: seorang pelajar atau mahasiswa bergaul dengan temannya dan mendapatkan tentang cyber sex hasil obrolan yang dilakukan secara beramai. Tentu saja pada obrolan selanjutnya tidak ingin ketinggalan, maka dia mencoba mencari tahu sendiri denganmasuk ke situs cyber sex tersebut.

\section{Ekonomi}

Teknologi informasi telah mengubah perilaku dan pola hidup masyarakat global. Perkembangan teknologi informasi telah pula menjadikan dunia tanpa batas dan menyebabkan perubahan ekonomi secara signifikan berlangsung demikian cepat. Teknologi informasi saat ini menjadi pedang bermata dua, karena selain memberikan kontribusi bagi peningkatan kesejahteraan, kemajuan, dan peradaban manusia, sekaligus menjadi sarana efektif perbuatan melawan hukum. Minimnya informasi dan meluasnya cyber sex di Indonesia, memotivasi perlunya kajian yang berkaitan dengan intensitas mengakses situs seks dan permisivitas pelaku seksual remaja. ${ }^{12}$

Perkembangan cyber sex tanpa disadari menimbulkan hal-hal negatif. Mungkin karena sifat internet yang bebas dan terbuka untuk siapa saja. Industri seks di Indonesia sangat besar secara ekonomi dan permintaan semakin banyak. Wisata seks dan pedofilia masih terus terjadi di Bali, bagaikan gunung es yang baru terlihat pada permukaan akibat timbulnya cyber sex.

${ }^{12}$ Sugiarto Ouk, Cyber Crime Motif dan Penindakan, Jakarta : Grafindo Indah, 2005, hlm. 76 
Inilah yang dinamakan simbiosa mutualistis atara industri seks virtual dan internet, sama-sama saling membutuhkan dan saling membantu. Itu baru dari segi teknologi. Bahkan akses terhadap situs-situs seks begitu besarnya sehingga menghasilkan nilai omset sementara dengan 1,3 miliyar dolar Australia setahunnya. Tidaklah mengejutkan seberapa besar kenaikan peran serta wanita dalam industri seks dimaksud, sebatas komsumen tentu saja, dibandingkan 10 tahun silam, saat wanita hanya mengkonsumsi kira-kira $10 \%$ saja dari produk-produk pornografi online, sementara sampai hari ini jumlahnya meningkat menjadi melebihi $40 \%$. Kehidupan alternatif atau pelarian masyarakat barat pada realitas kehidupan masyarakat modern yang bagi kumpulan subbudaya di Barat sedang menuju kehancuran.

\section{Cyber Sex dalam Hukum Islam}

Tanpa disadari internet telah berkembang. Banyak manfaat positif yang didapat dengan internet, tetapi banyak juga manfaat negatifnya, salah satunya adalah fenomena ribuan situs-situs porno bermunculan. Keberadaan situs porno tersebut seolah tak terbendung setiap hari jumlahnya bertambah banyak.

Cyber sex tidak berbeda dengan pornografi. Pornografi selalu dikaitkan dengan bentuk lekukan tubuh yang sensual dari perempuan atau laki-laki yang dapat membangkitkan nafsu birahi bagi lawan jenis maupun sejenis. Perbuatan tersebut tentu saja tergantung kepada pemilik tubuh pelaku yang tidak lepas dari prinsip kepemilikan tubuh masing-masing.

Menurut ajaran Islam, tubuh manusia merupakan amanah Allah, bagi pemilik tubuh yang bersangkutan wajib dipelihara dan dijaga dari perbuatan tercela dan terjerumus dalam kemaksiatan.

Islam telah mengantisipasi mengenai hal keburukan yang dapat ditimbulkan dari pornografi dan pornoaksi, dan hal tersebut tertuang dalam beberapa surat dalam al-Quran, yaitu:

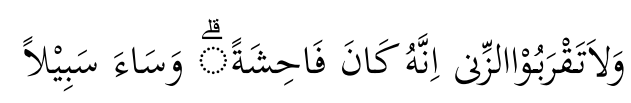


Artinya: "Dan janganlah kamu mendekati zina, sesungguhnya zina itu adalah suatu perbuatan keji, dan suatu jalan yang buruk." (QS. al-Isra': 32)

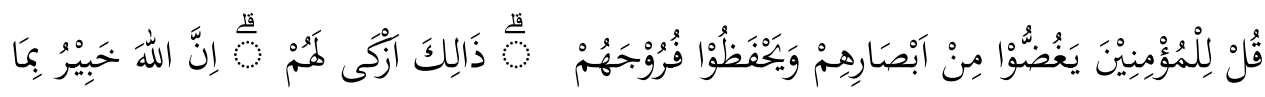
يَصْنَعُوْنَ

Artinya: "Katakanlah kepala laki-laki yang berima : hendaklah mereka menahan pandangnnya, dan memelihara kemaluannya, yang demikian itu ialah lebih suci bagi mereka, sesungguhnya Allah maha mengetahui apa yang mereka perbuat.13" (QS. An-Nur : 30-31)

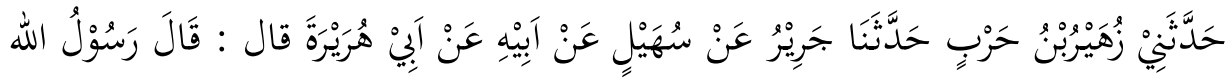

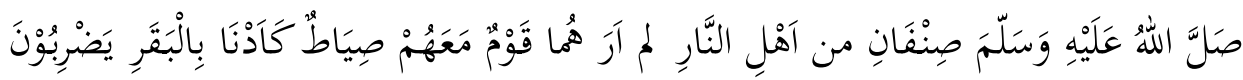

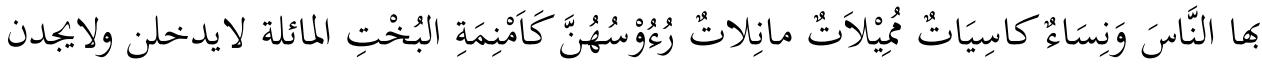

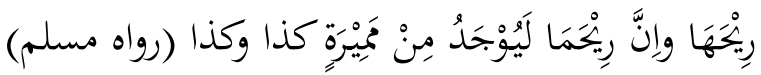

Artinya: "Diriwayatkan oleh Zuhair bin Harb dan Jarir dari Suhail dari ayahnya dari abu Hurairah, beliau berkata: Rosulullah bersabda: Dua macam dari ummat (calon penghuni neraka) yang belum aku pernah melihatnya: satu golongan yang menggunakan pecut seperti ekor sapisapi untuk memukuli orang dan segolongan perempuan yang berbusana telanjang, melenggok-lenggokkan jalannya untuk menjerat mangsanya, kepala seperti punuk unta yang miring, mereka tidak masuk surge dan tidak mencium banunya, padahal baunya tercium dari jarak sekian dan sekian. (HR. Muslim)

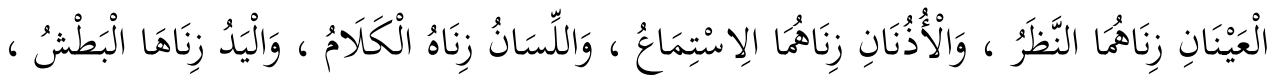

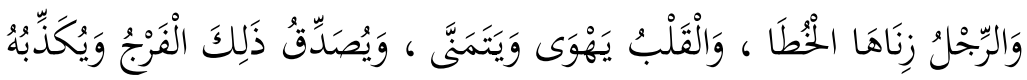

${ }^{13}$ Muslimah, Al-Quran dan Tarjemah Untuk wanita, Bandung : jabal, 2016, hlm. 350. 
Artinya: "Mata zinanya melihat, telinga zinanya mendengar, lidah zinanya berbicara, tangan zinanya memegang, kaki zinanya melangkah, dan hati zinanya gairah dan bayangan pikiran kotor. Sementara kemaluan yang akan membenarkan atau mendustakan terjadinya zina sesungguhnya." (HR. Muslim).

Majelis Ulama Indonesia (MUI) merekomendasikan melalui keputusan Fatwa MUI Nomor 287 tahun 2001 tentang pornografi dan porno aksi, pada tanggal 22 Agustus 2001, yang putusannya sebagai berikut.

1. Menggambarkan secara langsung atau tidak langsung tingkah laku secara erotis, baik dengan lukisan, gambar, tulisan, suara, reklame, iklan, maupun ucapan baik melalui media cetak maupun elektronik yang dapat mengakibatkan nafsu birahi adalah haram.

2. Memperbanyak, mendengarkan, menjual, maupun membeli dan melihat ataupun memperlihatkan gambar orang, baik cetak maupun visual yang terbuka auratnya atau berpakaian ketat atau tembus pandang yang dapat mengakibatkan nafsu birahi, atau gambar hubungan seksual atau adegan seksual adalah haram.

Meskipun pengaturan tersebut tidak menjelaskan langsung terhadap cyber sex tetapi dapat dijadikan suatu pertimbangan dalam menangani masalah cyber sex yang semakin berkembang.

\section{Cyber Sex Dalam UU. No. 44 Tahun 2008 Tentang Pornografi}

Cyber sex merupakan pornografi dan porno aksi yang dilakukan melalui internet. Maka hal tersebut dapat melihat UU. No. 44 tahun 2008 tentang pornografi dengan menggunakan penafsiran dan penerapannya. Pasal 1

1. Pornografi adalah gambar, sketsa, ilustrasi, foto, tulisan, suara, bunyi, gambar bergerak, animasi, kartun, percakapan, gerak tubuh, atau bentuk pesan lainnya melalui berbagai bentuk media komunikasi dan/atau pertunjukan di muka umum, yang memuat kecabulan atau 
eksploitasi seksual yang melanggar norma kesusilaan dalam masyarakat.

2. Jasa pornografi adalah segala jenis layanan pornografi yang disediakan oleh orang perseorangan atau korporasi melalui pertunjukan langsung, televisi kabel, televisi teresterial, radio, telepon, internet, dan komunikasi elektronik lainnya serta surat kabar, majalah, dan barang cetakan lainnya.

3. Setiap orang adalah orang perseorangan atau korporasi, baik yang berbadan hukum maupun yang tidak berbadan hukum.

4. Anak adalah seseorang yang belum berusia 18 (delapan belas) tahun.

5. Pemerintah adalah Pemerintah Pusat yang dipimpin oleh Presiden Republik Indonesia yang memegang kekuasaan pemerintahan negara Republik Indonesia sebagaimana dimaksud dalam Undang-Undang Dasar Negara Republik Indonesia Tahun 1945.

6. Pemerintah Daerah adalah Gubernur, Bupati, atau Walikota, dan perangkat daerah sebagai unsur penyelenggara pemerintahan daerah.

\section{Pasal 281 KUHP}

Diancam dengan pidana penjara paling lama dua tahun delapan bulan atau pidana denda paling banyak empat ribu lima ratus rupiah:

1. Barang siapa dengan sengaja dan terbuka melanggar kesusilaan;

2. Barang siapa dengan sengaja dan di depan orang lain yang ada di situ bertentangan dengan kehendaknya, melanggar kesusilaan.

\section{Pasal 282 KUHP}

1. Barang siapa menyiarkan, mempertunjukkan atau menempelkan di muka umum tulisan, gambaran atau benda yang telah diketahui isinya melanggar kesusilaan, atau barang siapa dengan maksud untuk disiarkan, dipertunjukkan atau ditempelkan di muka umum, membikin tulisan, gambaran atau benda tersebut, memasukkannya ke dalam negeri, meneruskannya, mengeluarkannya dari negeri, atau memiliki persediaan, ataupun barang siapa secara terang-terangan atau dengan mengedarkan surat tanpa diminta, menawarkannya atau menunjukkannya sebagai bisa diperoleh, diancam dengan pidana 
penjara paling lama satu tahun enam bulan atau pidana denda paling tinggi empat ribu lima ratus rupiah.

2. Barang siapa menyiarkan, mempertunjukkan atau menempelkan di muka umum tulisan, gambaran atau benda yang melanggar kesusilaan, ataupun barang siapa dengan maksud untuk disiarkan, dipertunjukkan atau ditempelkan di muka umum, membikin, memasukkan ke dalam negeri, meneruskan mengeluarkannya dari negeri, atau memiliki persediaan, ataupun barang siapa secara terang-terangan atau dengan mengedarkan surat tanpa diminta, menawarkan, atau menunjuk sebagai bisa diperoleh, diancam, jika ada alasan kuat baginya untuk menduga bahwa tulisan, gambaran atau benda itu melanggar kesusilaan, dengan pidana paling lama sembilan bulan atau pidana denda paling banyak empat ribu lima ratus rupiah.

3. Kalau yang bersalah melakukan kejahatan tersebut dalam ayat pertama sebagai pencarian atau kebiasaan, dapat dijatuhkan pidana penjara paling lama dua tahun delapan bulan atau pidana denda paling banyak tujuh puluh lima ribu rupiah. ${ }^{14}$

Pasal 27 ayat 1 UU ITE

Setiap orang dengan sengaja dan tanpa hak mendistribusikan dan/atau mentransmisikan dan/atau membuat dapat diaksesnya informasi elektronik dan/atau dokumen elektronik yang memiliki muatan yang melanggar kesusilaan.

\section{Dampak Cyber Sex Terhadap Remaja}

Dalam kamus Bahasa Indonesia, kata remaja berarti sudah sampai umur (anak laki-laki atau perempuan) putera atau puteri, berumur 12-15 tahun. ${ }^{15}$ Dan dalam kamus umum Bahasa Indonesia, remaja adalah dikatakan kepada anak wanita yang mulai haid dan anak laki-laki yang sudah akil baligh.

\footnotetext{
${ }^{14}$ Andi Hamzah, KUHP \& KUHAP, Jakarta : Rineka Cipta, 2014, hlm. 111.

${ }^{15}$ Eddy Soetritno, Kamus Populer Bahasa Indonesia, Jakarta : Balai pustaka,
} 2006, hal. 42 . 
Pornografi tak beda jauh dengan narkotika. Keduanya memberi candu dan memberi efek yang membahayakan, tidak hanya diri pelaku melainkan masyarakat sekitarnya. Pornografi potensial melahirkan permisivitas seks yang karenanya muncul seks bebas (free sex), pemerkosaan dan pelecehan seksual terhadap perempuan.

Efek negatif lain yang tak kalah bahayanya adalah menimpa anakanak. Ketika anak suka melihat gambar porno melalui televisi, penjaja koran dan majalah, maka bacaan tersebut dapat mempengaruhi libiditas seksual anak. Jika seorang anak SD sebelumnya tabu mempermainkan anak perempuan sebaya, melalui pornografi mereka akan melakukan pembenaran atas perilaku yang sebelumnya dia anggap sebagai tabu. Seorang pelajar SMP, SMA, dan perguruan tinggi, akan terlecut libiditas seksualnya manakala sering melihat tayangan atau bacaan pornografi, secara keseluruhan, pornografi memberi efek tidak baik bagi siapa saja, tanpa memandang usia, jenis kelamin, pendidikan dan status sosial. ${ }^{16}$

Dampak negatif yang timbul dari adanya cyber sex bagi remaja adalah:

1. Kecanduan akan internet yang dikenal dengan istilah "internet addiction disorder". Beberapa ciri orang yang mengalami internet addiction disorder antara lain: semakin sering menggunakan internet, waktu yang digunakan untuk online lebih banyak daripada waktu yang digunakan untuk kegiatan lain, mengalami gangguan atau lebih seperti gangguan psikomotor, bermimpi atau berfantasi tentang internet, serta adanya perasaan sangat terganggu atau sangat bermasalah ketika mematikan koneksi internet. ${ }^{17}$

2. Tidak peduli dengan masa depan

Di Jakarta pernah ditemukan kasus banyaknya siswa yang ketagihan online, para siswa sampai lupa waktu bahkan sampai memakai uang bayaran sekolah. ${ }^{18}$ Menurunnya prestasi kerja atau pun akademis,

\footnotetext{
${ }^{16}$ Chairil Adjis dkk, Kriminologi Syariah Kritik Terhadap Sistem Rehabilitasi, Jakarta : RM books, 2007 cet. 1, hal.93.

17 “Cyber Sex", http://www.kapanlagi.com/clubbing/view topic cyber sex, diakses pada tanggal 12 januari 2018, pukul 04.30
} 
berkurangnya interaksi sosial, terjadinya gangguan tidur (kurang tidur), makin maraknya cyber sex dan cyber-affair, terganggunya hubungan pasangan/perkawinan.

Akibat gencarnya ekspose seks di media masa, menyebabkan remaja modern kian terbuka terhadap seks. Jika masa silam, buku klasik tentang seks yang bertajuk kama sutra hanya dibaca oleh orang tua dan selalu disembunyikan, maka sekarang orientasi telah berubah. Buku tersebut telah menjadi barang laris di toko buku, dan dikonsumsi oleh berbagai kalangan, termasuk remaja. Bukan menjadi suatu keanehan pula apabila remaja di masa sekarang lebih mengenal berbagai buku yang menonjolkan pornografi dan blue film daripada orang tuanya. Hal ini menunjukkan bahwa di era sekarang pandangan remaja terhadap seks telah mengalami pergeseran bahkan sangat jauh sekali. ${ }^{19}$

Di antara budaya akibat cyber sex ini, terutama bagi mental dan pola pikir pria yang belum menikah adalah pengaruh paling kecil, cyber sex akan mendorong seseorang berfantasi tentang hubungan seks. Ketika tingkat birahi telah tinggi, seseorang akan memuaskan hal itu, namun ketika sarana-sarana ke arah kepuasan ini tidak ada. Maka cyber sex memberikan fatamorgana negatif dalam daya khayal mereka yang berakibat, mereka tersiksa dari sudut mental karena tidak adanya penyaluran (mereka yang belum nikah). Dan juga mengganggu proses berpikir kreatif.

3. Terjadinya penyimpangan perilaku seksual

Akibat cyber sex dapat memicu tindakan pemuasan seksual dengan diri sendiri. Hal ini juga bisa para remaja dapat melakukan perbuatan yang dilarang oleh agama dan hukum positif seperti tindakan kesusilaan. Tidak sedikit ABG melakukan penyimpangan seksual secara keroyokan bersama teman-temannya setelah terlebih dahulu menonton porno secara bersama-sama.

Demikian pula terhadap perbuatan onani atau masturbasi yang dilakukan di depan umum, baik yang diakibatkan oleh tindak pidana pornografi atau tindak pidana pornoaksi maupun tidak, namun dijatuhi

${ }^{19}$ Abu Al-Ghifari, Perbikahan Dini, Dilema Generasi Ekstravaganza, Bandung : Mujahid press, 2000, cet. Ke-2, hal. 38-39. 
hukuman berdasarkan ta'zir. Hal ini perlu dikemukakan, karena saat ini sering terjadi perbuatan onani atau masturbasi dilakukan di tempat penyewaan internet (tempat umum) yang disebut on-cyber sex, sebagai akibat visualisasi pornografi melalui situs internet yang ditontonnya. ${ }^{20}$ Anak yang masih belia, karena sering menonton film porno mendadak berubah insting seksnya menjadi benar-benar dewasa. Anak kecil tersebut telah menjadi generasi hewani yang lebih mengedepankan nafsu dibandingkan nalar.

Dalam hal ini tanggungjawab segenap lapisan masyarakat untuk menanggulangi cyber sex. Tugas masyarakat tidak hanya mengurangi angka kejahatan semata, melainkan juga ikut menganalisis, mengenal dan memahami ancaman kejahatan tersebut, termasuk dalam hal ini adalah cyber sex. Pemblokiran konten porno di internet oleh Kementrian Informasi dan Komunikasi sangat efektif dalam menurunkan akses pornografi internet di Indonesia.

\section{Kesimpulan}

Pornografi merupakan salah satu permasalahan mendasar sebagai akibat dari perkembangan teknologi informasi dan komunikasi saat ini. Meskipun pemblokiran situs penyedia konten pornografi dilakukan, tetapi permasalahan pornografi melalui cyber sex masih menjadi persoalan bersama.

Dalam hukum Islam masalah pornografi dan pornoaksi memang tidak diatur secara eksplisit dalam Al-Qur'an tapi Islam telah jauh mengatur tentang larangan mendekati zina dan larangan berkhalwat. Karena hukum Islam bukan hanya mengatur tentang perbuatan yuridis saja tapi mengandung unsur normatif di dalamnya.

Konsep hukum Islam mengenai pornografi dan pornoaksi menggunakan kaidah maslahah mursalah yang berasaskan keadilan dan sadd adz-dzari'ah. Adanya siyasah syari'ah yakni kebijaksanaan untuk membuat masyarakat lebih dekat dan lebih gemar pada kebijakan,

${ }^{20}$ Neng Djubaedah, Pornografi dan Pornoaksi, Bogor : Kencana, 2003, hlm. 163. 
menjauhi dan membenci keburukan dan kerusakan, dimaksudkan untuk merealisasikan kemaslahatan manusia. Majelis Ulama' Indonesia (MUI) sebagai lembaga yang mempunyai wewenang untuk menyerukan umatnya kepada amar ma'ruf nahi munkar juga mengeluarkan fatwa tentang larangan pornografi dan pornoaksi. Karena ulama' sebagai pewaris para Nabi memandang bahwasanya pornografi dan pornoaksi banyak mendatangkan kemadharratan dari pada kemanfaatan. Dan sebagai bukti bahwa ulama' menjadi benteng terhadap persoalan etika dan moral.

Hukum positif (KUHP) juga tidak mengatur tentang pornografi dan pornoaksi, dalam pasal 281, 282, dan 283 hanya mengatur tentang kejahatan kesusilaan. Walaupun pasal tersebut menegaskan juga untuk memberantas pornografi dan pornoaksi tapi KUHP masih memberi ruang bagi pelaku untuk mengulangi perbuatannya apabila tidak terbukti secara legal formal.

Pengguna internet untuk mengakses situs-situs porno sangat gampang dan sulit untuk dihindari, mengingat situs-situs semacam ini tersedia sangat banyak dalam dunia maya. Meskipun pemblokiran konten-konten pornografi dilakukan, penyebaran masih marak terjadi dalam industry cyber sex dunia. Tergantung bagaimana individu cerdas dan positif dalam menggunakan internet.

\section{DAFTAR PUSTAKA}


Adjis, Chairil \& Dudi Akasyah. 2007. Kriminologi Syariah Kritik Terhadap Sistem Rehabilitasi. Jakarta: RM books

Ahmad, Djazuli. 1991. Figh Jinayah Upaya Menanggulangi Kejahatan Dalam Islam. Jakarta: PT. Raja Grafindo Persada

Ahmad, Hamzah. 1987. Pornografi dalam Hukum Pidana, Suatu Studi Perbandingan. Jakarta: Bina Mulia

Ali, Muhammad Daud. 2007 dan 2000. Hukum Islam: Pengantar Ilmu Hukum dan Tata Hukum Islam di Indonesia. Jakarta: Raja Grafindo Persada

Ali, Muhammad Daud. 2007. Pengantar Ilmu Hukum dan Tata Hukum Islam di Indonesia, Jakarta: Raja Grafindo Persada

Al-Maliki, Abdurahman. 1990. Nidzam al-Uqubah, Beirut: Dar al-Ummah

Al-Ghifari, Abu. 2000. Pernikahan Dini, dilema Generasi Ekstravaganza. Bandung: Mujahid press

Amiruddin, Zainal Asikin. 2013. Pengantar Metode Penelitian Hukum. Jakarta : Rajawali Pers

Anwar, Moch. 2012. Beberapa Ketentuan Umum dalam Buku Pertama KUHP, Bandung: Cahaya Ilmu

Aoi Sora "Awas bahaya Cyber Sex"http://bunnitt.blogspot.co.id/ 2011/08/awas-bahaya-cyber-sex.html di akses pada tanggal 27 Desember 2017, Pukul 19.00 WIB.

Arief, Barda Nawawi. 1996. Bunga Rampai Kebijakan Hukum Pidana. Bandung: PT. Citra Aditya

Ash-Shiddiqi, Hasbi. 2001. falsafah Hukum Islam. Semarang: Pustka Rizki Putra.

Dahlan, Abdul Aziz, 1996. Ensiklopedi Hukum Islam. Jakarta: Ichtiar Baru Van Hoave. 
Depertemen Pendidikan dan Kebudayaan Republik Indonesia. 1995. Kamus Besar Bahasa Indonesia. Jakarta: Balai Pustaka.

Depertemen Agama RI. 2000. Al-Qur'an dan terjemahnya, Semarang: TohaPutra.

Eriyansyah, Agus. 2008. Cyber Sex Menurut Hukum Islam dan Hukum Positif, Jakarta: Universitas Syarif Hidayatullah

Makarim, Edmon. 2003. Kompilasi Hukum Telematika, Jakarta: PT. Raja Grafindo Persada

Hamzah, Andi. 2012. KUHP (Kitab Undang-Undang Hukum Pidana. Jakarta: Rineka Cipta

Fuady, Munir. 2010. Perbandingan Ilmu Hukum. Bandung: Refika Aditama

Hajar, Asqalani Ibn. al- Bulughul Maram. Jakarta: Dar Al-Kutub AlIslamiyah

Hartono, Jogiyanto. 1999. Pengenalan Computer. Yogyakarta: Andi

Johnny Ibrahim. 2006. Teori Dan Metodologi Penelitian Hukum Normatif. Malang : Bayumedia

Koesnoe, Moh. 1992. Hukum Adat Sebagai Suatu Model Hukum. Bandung: Mandar Maju

Mahsun, Fuad. 2005. Hukum Islam di Indonesia. Yogyakarta: LkiS.

Malik, Ibn Anas. 1951, Al-Muwatta' juz. 2 Mesir: Musthofa al-Tsani al-Janbi

Mansur, Didik M. Arif dan Elisatris Gultom. 2006. Ciber Law Aspek Hukum Teknologi. Bandung: PT Refika Aditama

Moeljatno. 1987. Asas-asas Hukum Pidana. Jakarta: Bina Aksara

Minhajuddin. 1983. Pengantar Ilmu Figh-Ushul Figh, Ujungan Pandang: Fakultas Syariah IAIN Alauddin 
Muchsin. 2002. Hukum Islam dalam Persepektif dan Prospektif. Surabaya: Yayasan Al Ikhlas.

Muslimah. 2016. Al-Quran dan Tarjemah Untuk wanita, Bandung: Jabal.

Mustafa, Bahsan. 2003. Sistem Hukum Indonesia Terpadu. Bandung: Citra Aditya Bakti.

Neng, Djubaedah. 2003. Pornografi dan Porno Aksi. Bogor: Kencana.

Neng, Djubaedah. 2004. Pornografi dan Pornoaksi ditinjau dari Hukum Islam. Jakarta: Kencana.

Rahman, Fatchur. 2002. Dasar-dasar Pembinaan Hukum Figh Islamy. Jakarta: Sa'adiyah Putra.

Rosyada, Dede. 1992. Hukum Islam \& Pranata Sosial, Jakarta: Lembaga Studi Islam \& Kemasyarakatan.

Sahal, Mahfudh. 1994. Nuansa Figh Sosial, Yogyakarta: Lkis Bekerjasama dengan Pustaka Pelajar. 